\title{
GREEN SYNTHESIS OF SILVER NANOPARTICLES OF ONION DNA AND SCREENING FOR IN VITRO ANTITYROSINASE ACTIVITY
}

\author{
SNEHA THAKUR ${ }^{1 *}$, KRISHNA MOHAN $G^{2}$ \\ ${ }^{1}$ Department of Pharmacognosy, Bojjam Narasimhulu Pharmacy College for Women, Hyderabad, Telangana, India. ${ }^{2}$ Department of \\ Pharmacognosy, Centre for Pharmaceutcial Sciences, Indian Standard Time, Jawaharlal Nehru Technological University, Hyderabad, \\ Telangana, India. Email: snehathakur2189@gmail.com \\ Received: 01 July 2019, Revised and Accepted: 30 July 2019
}

\section{ABSTRACT}

Objective: The main objective of the research work is to evaluate the antityrosinase potential of onion DNA silver nanoparticles (AgNPs).

Methods: The onions were procured from the local market and DNA was extracted from onions using detergent and methylated spirit. The isolated DNA was selected for synthesis of AgNPs which acts as capping and reducing agent. About $10 \mathrm{ml}$ of the DNA extract was added to $90 \mathrm{ml}$ of $0.1 \mathrm{~N}$ silver nitrate solution. After $24 \mathrm{~h}$ incubation, the solution turned dark brown, which indicates the formation of AgNPs. The synthesized DNA AgNPs were characterized by ultraviolet-visible, Fourier transform infrared (FTIR), scanning electron microscopy (SEM), X-ray diffraction (XRD), and dynamic light scattering (DLS) studies.

Results: The results revealed that the particles were uniform in shape with face-centered cubic structure. The particles are $153 \pm 20.4 \mathrm{~nm}$ in size and were no signs of agglomeration measured by DLS studies. The FTIR spectroscopy revealed B form of DNA along with strong N-H stretching, $\mathrm{C}=\mathrm{N}$ stretching, and also asymmetric vibrations of phosphate groups characteristic for DNA molecule. The XRD studies revealed the face-centered cubic structure. SEM studies revealed the spherical structure with average particle size of $150 \pm 0.1 \mathrm{~nm}$ for single DNA nanoparticles. The onion DNA AgNPs were further investigated for its antityrosinase activity against the standard kojic acid and were to have anticancer potential nearer to the standard.

Conclusion: From the results, it is evident that the synthesized onion DNA AgNPs have antityrosinase potential and can be further investigated for in vivo anticancer potential in future.

Keywords: DNA, Silver nanoparticles, Antityrosinase activity, Kojic acid.

(c) 2019 The Authors. Published by Innovare Academic Sciences Pvt Ltd. This is an open access article under the CC BY license (http://creativecommons. org/licenses/by/4. 0/) DOI: http://dx.doi.org/10.22159/ajpcr.2019.v12i9.34745

\section{INTRODUCTION}

DNA nanoparticles are integrated structures that are functionalized due to their synergistic combination of augmented properties. The DNA which is genetic material when encapsulated in silver nanoparticle (AgNPs) is a value-added combination leading to their new revolution for potent combined activity [1]. DNA-encapsulated AgNPs are found to have wider applications that include biosensing, labeling, targeted imaging, cellular delivery, diagnostics, therapeutics, theranostics, bioelectronics, and biocomputing [2]. AgNPs are in the current trend of therapeutics due to their unusual physiochemical properties such as chemical stability and electrical conductivity and also due to wide range of biological activities such as antibacterial, antifungal, antiinflammatory, antiviral, antiangiogenesis, anticancer, and antiplatelet activities [3]. AgNPs are also used clothing, room spray, laundry detergent, wall paint formulation, sunscreens, and cosmetics. AgNPs also inhibit HIV-1 virus from binding to the host cells in vitro [4]. The DNA extraction can be easily performed by any of three methods such as chemical, physical, or enzymatic degradations and later following a bottom to top approach for the synthesis of DNA-encapsulated AgNPs. The DNA can be obtained from any biological material such as living or conserved tissues, cells, virus particles, or other samples for analytical or preparative purposes $[5,6]$. Thus, DNA is extracted using standard procedures and purified. The extracted DNA is further integrated into the silver conjugate of nanoparticle using bottom to top approach. The DNA-encapsulated AgNPs are characterized by dynamic light scattering (DLS) for particle size, atomic force microscopy and scanning electron microscopy (SEM) for size distribution and shape of nanoparticular structure, etc. [7].
The novelty of this study lies in synthesizing the DNA nanoparticles which is new revolution in nanotechnology due to its profound pharmacological effects at molecular level. In our present research, the DNA was extracted from onion (Allium cepa L.). The extraction of DNA from onion is simple and rapid. The plant A. cepa $\mathrm{L}$. was selected as it is rich in bioactive compounds with potential beneficial health effects. The onion is used as traditional and folk medicine. It is used daily in foods due to its positive health effects. The pharmacological activity of onion includes antibacterial activity, hypocholesterolemic, hypolipidemic, antihypertensive, antithrombotic, and hypoglycemic activities, wound healing activity, antioxidant, anti-inflammatory, asthma-protective agent, and anticancer activity. The possible reported activities are due to the presence of organic sulfur compounds along with organoselenium compounds, flavonols (quercetin and its glucosides), and dietary fiber (fructans and fructooligosaccharides) [8]. The DNA from onion is extracted by simple chemical degradation process where mechanical disruption of cell wall causes the DNA to precipitate and become visible. The extracted DNA is further integrated with silver nanoconjugate to produce DNA-encapsulated AgNPs.

Our present research is focused on the synthesis of onion DNAencapsulated AgNPs and to further investigate its antityrosinase activity.

\section{METHODS}

\section{Extraction of onion DNA}

The DNA from onion was extracted using standard procedure [9]. The onions were obtained from local market in Hyderabad, Telangana, 
India. They were washed cleaned and chopped into six $1 \mathrm{~cm} \times 1 \mathrm{~cm}$ fine pieces using sharp knife. Crush and grind the onion pieces until a homogenous, smooth paste is achieved. About $200 \mathrm{ml}$ (1 cup) of the water was measured and poured this into a glass and one teaspoon of salt was added. The salty water was heated at $55-60^{\circ} \mathrm{C}$ for $1 \mathrm{~min}$ (high) on a preheated water bath later stirred well. The mixture was further blended for about $10 \mathrm{~s}$. The onion-salt-water mixture was poured through the strainer and the liquid was collected in a glass. The DNA from the onion is in this liquid. About $50 \mathrm{ml}$ (1/4 cup) of the onion liquid were measured out and poured into a glass, then added with two teaspoons of dishwashing detergent to the glass containing the $50 \mathrm{ml}$ (1/4 cup) of onion liquid. Then, the mixture was stirred very gently. About $100 \mathrm{ml}$ (1/2 cup) of methylated spirits was measured and slowly added the methylated spirits to the glass containing the onion-detergent mixture. The mixture was allowed to stand for few minutes for the DNA to appear. The DNA is white, rising up from the bottom of the glass. The extracted DNA is further characterized and later used to conjugate with silver nitrate of suitable concentration to synthesize AgNPs.

\section{Preparation of $0.1 \mathrm{~N}$ silver nitrate solution}

Silver nitrate chemical was procured from Sigma-Aldrich Chemicals. About $1.6987 \mathrm{~g}$ of pure silver nitrate was accurately weighed and dissolved in water and the volume was adjusted to $100 \mathrm{ml}$.

Green synthesis of AgNPs of onion DNA (bottom to top approach) The purified DNA extract was prepared. About $10 \mathrm{ml}$ of the DNA extract was added to $90 \mathrm{ml}$ of $0.1 \mathrm{~N}$ silver nitrate solution. After $24 \mathrm{~h}$ incubation, the solution turned dark brown, which indicates the formation of AgNPs. Solution was then transferred into a round bottom flask and was heated with continuous stirring at $90^{\circ} \mathrm{C}$. After $15 \mathrm{~min}$, the centrifugation was done at room temperature and a speed of $9000 \mathrm{rpm}$. A dark brownish-black powder was obtained after washing thrice with distilled water was dried overnight in an oven at $80^{\circ} \mathrm{C}[10]$.

\section{Characterization of synthesized DNA AgNPs}

Optical absorption of green synthesized AgNPs was studied using Fourier transform infrared (FTIR) (Shimadzu FT-IR) and ultraviolet (UV)-visible (Shimadzu UV-VIS 2550) spectral analysis, respectively. FTIR spectra were recorded using $\mathrm{KBr}$ pellets in the range of $3500-600 \mathrm{~cm}^{-1}$. The crystalline nature of green synthesized AgNPs was confirmed by X-ray diffraction (XRD) pattern. XRD data were recorded using Malvern X-ray diffractometer. Morphology, size, and electron diffraction pattern were examined by SEM.

\section{Particle size analysis and zeta potential}

Average particle size and polydispersity index of DNA AgNPs were determined using DLS technique. Zeta potential of prepared nanoparticles was determined using Zetasizer.

\section{Differential scanning calorimetry (DSC) analysis}

Physical state of all the components of silver DNA nanoparticles was investigated by DSC (Malvern), calibrated with an indium standard. All the analyses were performed at the heating rate of $10^{\circ} \mathrm{C} / \mathrm{min}$ up to $300^{\circ} \mathrm{C}$.

\section{Powder XRD analysis}

XRD analysis of all the components of silver DNA nanoparticles and physical mixture of DNA nanoparticles was performed using X-ray diffractometer (Malvern). The XRD parameters were set as follows: Scanning rate, 4 (deg/min) at a voltage of $40 \mathrm{kV}$ and $25 \mathrm{~mA}$, scanned angle; copper was used as a source of X-ray radiation.

\section{SEM}

The images of nanoparticles were obtained in the SEM (Carl Zeiss Evo 10 , OU University, Hyderabad). The instrument was operated at voltage of $15 \mathrm{kv}$.

\section{XRD studies}

The air-dried nanoparticles were coated onto XRD grid and analyzed for the formation of DNA AgNPs by X-ray diffractometer with Shimadzu
1830 X-ray generator operated at a voltage of $40 \mathrm{kv}$ and current of $30 \mathrm{~mA}$ with $\mathrm{Cu}$ Kal radiation. The diffraction intensities were recorded from $10^{\circ}$ to $80^{\circ}$ of 20 angles.

\section{FTIR spectroscopy analysis}

FTIR spectroscopy measurement, the sample was freeze-dried and diluted with potassium bromide in the ratio of 1:100 FTIR spectrum of samples which were recorded in BRUKER FTIR spectrophotometer instrument in the scanning range of $400-4000 \mathrm{~cm}$ at a resolution of $4 \mathrm{~cm}^{-1}$.

\section{RESULTS AND DISCUSSION}

The green synthesis method was followed for the preparation silver DNA nanoparticles where DNA acted as reducing and capping agent to reduce silver nitrate to silver ion that was characterized by various spectrophotometric methods. Further, they were screened for antityrosinase potential using standard kojic acid.

\section{UV-visible studies}

The UV-visible spectroscopic method (UV-2700) revealed the color change after the formation of nanoparticles. The silver nitrate solution exhibited no color and no broad peaks. When the onion DNA solution was added to silver nitrate solution and kept overnight for stirring, the visual perception of color change was observed form colorless to brown indicating the formation onion DNA AgNPs. The change in color is due to electron orientation that results in surface plasmon resonance (SPR) induced by imposition of electromagnetic field [11]. Fig. 1 shows SPR peak of the onion DNA nanoparticles at $410 \mathrm{~nm}$ characteristic for colloidal silver [12]. The SPR peak is redshifted due to the reduction of sliver ions in the aqueous solution of DNA assuming a fast reduction of free silver ions in solution and is followed by slow formation of AgNPs on DNA strands.

\section{DLS}

The average particle size distribution (Fig. 2) was studied using DLS (Malvern). The DLS measures the hydrodynamic diameter of the particle along with size of ion or the molecule attached to it and moves with AgNPs of the solution (Table 1). The ions or the molecule attached makes the particle appears larger and this size is particular to be

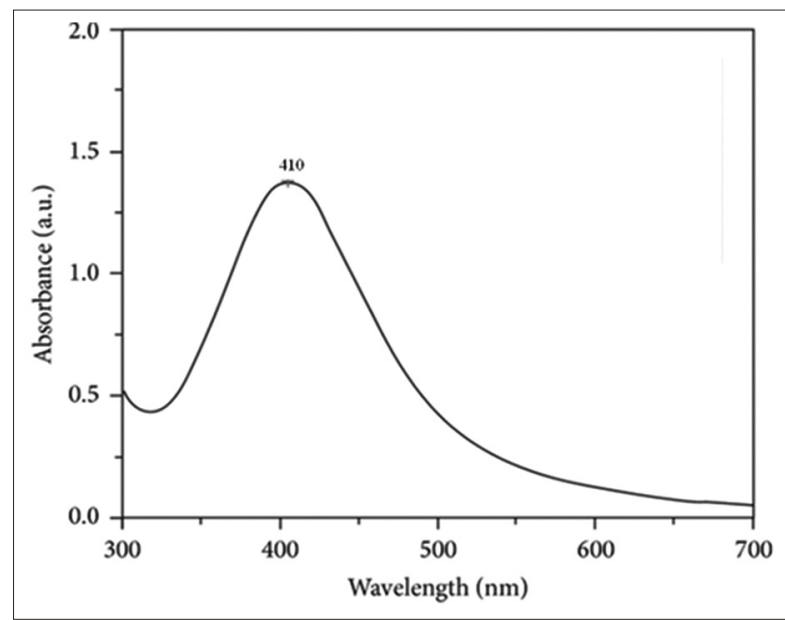

Fig. 1: Ultraviolet-visible spectrum of the onion DNA silver nanoparticles

Table 1: Particle size distribution of onion DNA silver nanoparticles

\begin{tabular}{llll}
\hline Parameter & Size (d.nm) & \% Intensity & Width (d.nm) \\
\hline $\begin{array}{l}\text { Particle size } \\
\text { distribution }\end{array}$ & $153.34 \pm 20.4$ & 95.4 & 118.4 \\
\hline \multicolumn{2}{l}{ The values are expressed in mean \pm S.D }
\end{tabular}


determined for the biological assay [13]. DLA measurements show that $95.4 \%$ of the particles have diameters of $153 \pm 20.4 \mathrm{~nm}$.

\section{Zeta potential}

The zeta potential was studied using Zetasizer (Malvern) to determine the stability $[14,15]$ of the synthesized DNA AgNPs using water as dispersant. The zeta potentialof the particles under study was found to be -28.6. $\mathrm{mV}$ (Fig. 3) which indicates that the surface of the DNA AgNPs is negatively charged (Table 2). The nanoparticles which have a zeta potential range between $+30 \mathrm{mV}$ and $-30 \mathrm{mV}$ are found to have good stability. The synthesized DNA AgNPs found to have good stability.

\section{FTIR characterization}

FTIR technique enables the chemical identification the molecule and is considered as one of the powerful analytical techniques. The FTIR spectra (Bruker) (Fig. 4) revealed the presence of DNA AgNPs was found to be in the region of $3500-400 \mathrm{~cm}^{-1}$ and it accounts for the variety of information on the conformational arrangement. The frequency range found between 3466 and $3179 \mathrm{~cm}^{-1}$ indicates nitrogen base region indicates strong $\mathrm{N}-\mathrm{H}$ stretching. The bands at 1650,1606 , and $1510 \mathrm{~cm}^{-1}$ indicate strong $\mathrm{C}=\mathrm{N}$ stretching. The frequency range 1450-1441 indicates strong $\mathrm{C}-\mathrm{H}$ bending of proteins. The possible interaction the silver ions can be observed in the region of $1300-800 \mathrm{~cm}^{-1}$. The B-form of DNA can be confirmed with bands at 1209,1107 , and $954 \mathrm{~cm}^{-1}$. The band at $1209 \mathrm{~cm}^{-1}$ confirms the asymmetric stretching vibration of phosphate groups. The shift of $1236-1207 \mathrm{~cm}^{-1}$ which is a characteristic of B form of DNA indicates a strong interaction between the DNA and the silver nitrate ions [16]. The reduction of silver ion can be identified by peaks at 695 and $635 \mathrm{~cm}^{-1}$.

Table 2: Zeta potential of onion DNA silver nanoparticles

\begin{tabular}{llll}
\hline Parameter & Mean $(\mathrm{mV})$ & Area $(\%)$ & Width $(\mathrm{mV})$ \\
\hline Zeta potential & $-28.6 \pm 2.6$ & 83.4 & 14.5 \\
\hline
\end{tabular}

The values are expressed in mean \pm S.D

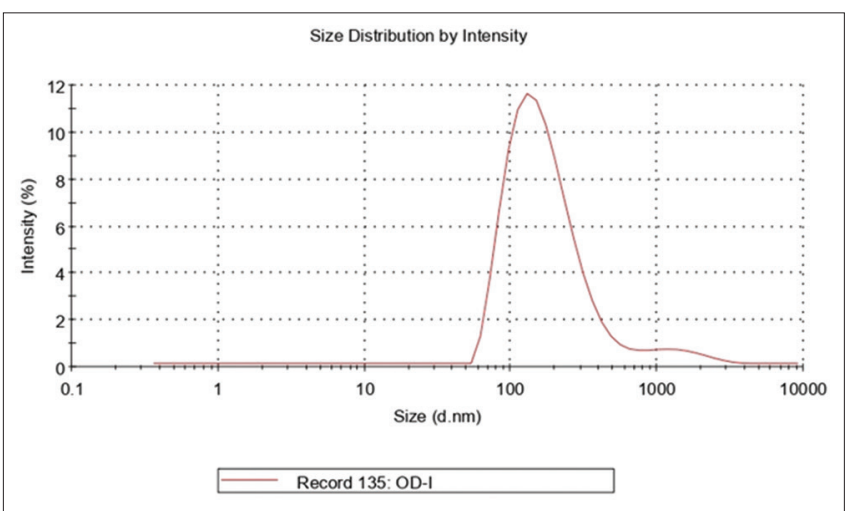

Fig. 2: Particle size analysis of the onion DNA silver nanoparticles

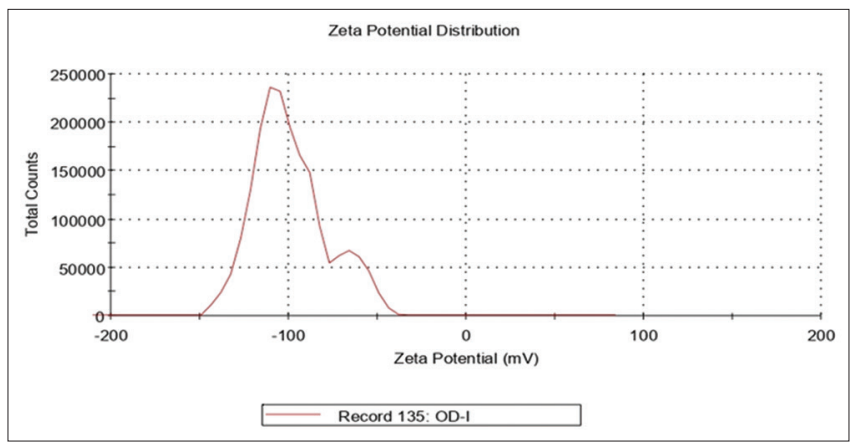

Fig. 3: Zeta potential graph of the onion DNA silver nanoparticles

\section{XRD analysis}

The XRD (Shimadzu) spectrum recorded was to confirm the crystalline structure of the synthesized DNA AgNPs as shown in Fig. 5. The diffraction peaks observed at $2 \theta$ values of $37.6,44.5,64.4$, and 77.4 corresponds to (111) (200), (220), and (311), respectively. The $2 \theta$ values reflect the face-centered cubic structure which suitably matched the standard diffraction data those reported for silver by joint committee on powder diffraction standards (JCPDS: 040783).

\section{SEM}

The SEM technique was employed to determine the size and morphology of the synthesized DNA AgNPs. They were found to be small spherical and fluorescent in nature [17]. SEM (Carl Zeiss Evo 10) image of DNA AgNPs with scale bars in $150 \pm 0.3 \mathrm{~nm}$ for single DNA AgNPs is shown in Fig. 6. The SEM image of DNA AgNPs is due to the interaction of hydrogen

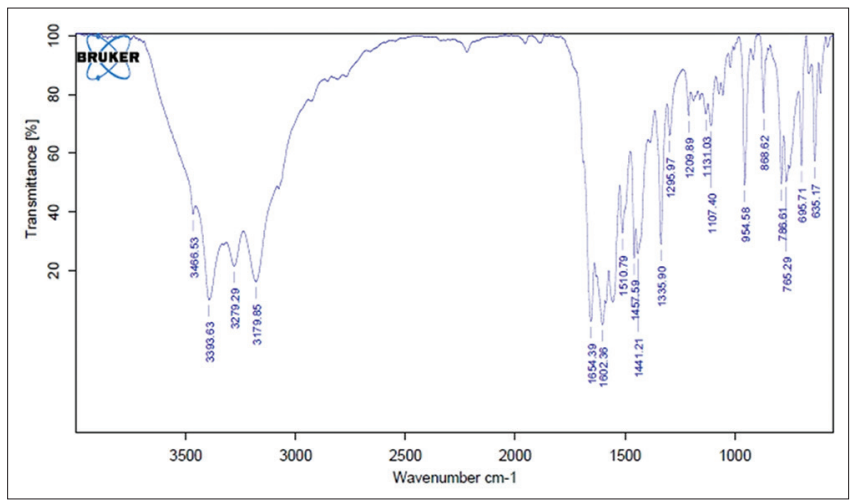

Fig. 4: Fourier transform infrared graph of the onion DNA silver nanoparticles

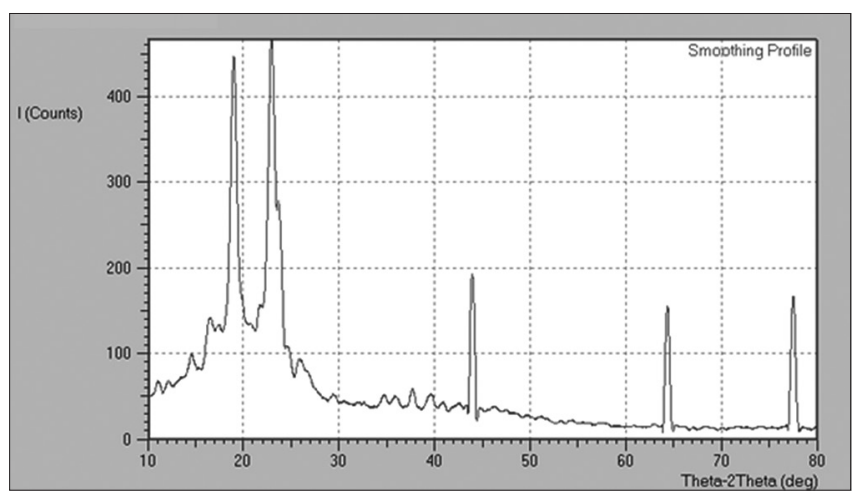

Fig. 5: X-ray diffraction graph of the onion DNA silver nanoparticles

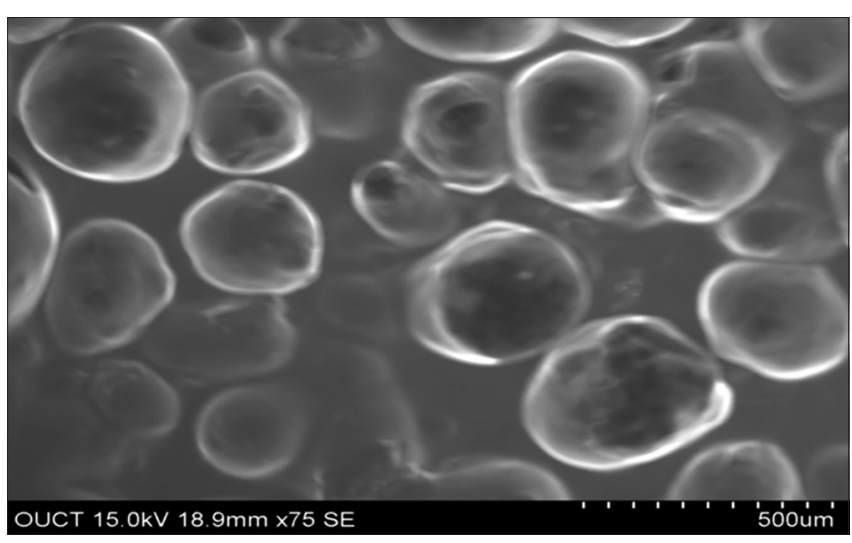

Fig. 6: Scanning electron microscopy graph of the onion DNA silver nanoparticles 
bonds and also electrostatic interactions between the bioorganic DNA capping molecules bound to the AgNPs. The nanoparticles did not form the aggregates, indicating nanoparticles stabilization by the DNA as capping agent.

\section{Screening for antityrosinase activity}

The tyrosinase inhibitory activity of onion DNA nanoparticles was determined by spectrophotometric method [18]. The compound was first dissolved in dimethyl sulfoxide (DMSO) at a concentration of $1.0 \mathrm{mg} / \mathrm{ml}$ and then diluted with different concentrations of DMSO. Each of the sample solution $(30 \mathrm{~mL})$ was diluted with $970 \mathrm{~mL}$ of $0.05 \mathrm{mM}$ sodium phosphate buffer ( $\mathrm{pH}$ 6.8) in the test tubes, followed by the addition of $1 \mathrm{ml}$ of $1 \mathrm{mg} / \mathrm{ml} \mathrm{L}$-tyrosine and finally $1.0 \mathrm{ml}$ of mushroom tyrosinase solution (200 units $/ \mathrm{mL}$ ). DMSO $(30 \mathrm{~mL})$ and kojic acid solution were used as blank reference and positive control, respectively. The reaction mixtures $(3.0 \mathrm{~mL})$ were mixed by vortex and the initial absorbance at $490 \mathrm{~nm}$ was measured. After incubation for $20 \mathrm{~min}$ at $37^{\circ} \mathrm{C}$, the final absorbance at the same wavelength was taken. The $\mathrm{IC}_{50}$ values which represent the concentrations of compounds at which $50 \%$ of the tyrosinase activity was inhibited were determined. The percent inhibition of tyrosinase activity was calculated as follows:

$\%$ Inhibition $=\frac{\left[\left(A_{2}-A_{1}\right)-\left(B_{2}-B_{1}\right)\right]}{\left(A_{2}-A_{1}\right)} \times 100$

Where, $A_{1}$ is the absorbance at $490 \mathrm{~nm}$ of the blank at $0 \mathrm{~min}$

$\mathrm{A}_{2}$ is the absorbance at $490 \mathrm{~nm}$ of the blank at $20 \mathrm{~min}$.

$\mathrm{B}_{1}$ is the absorbance at $490 \mathrm{~nm}$ of the test sample at $0 \mathrm{~min}$,

$\mathrm{B}_{2}$ is the absorbance at $490 \mathrm{~nm}$ of the test sample at $20 \mathrm{~min}$.

The compound $\mathrm{IC}_{50}$ value was found to be 29.27 and the standard $\mathrm{IC}_{50}$ value was found to be 46.52 . The compound OD- 1 has lower $\mathrm{IC}_{50}$ value when compared to the standard kojic acid (Fig. 7). Therefore, it has lower tyrosinase inhibitory activity when compared to the standard. Further, if studied, in vivo may produce promising results (Table 3).

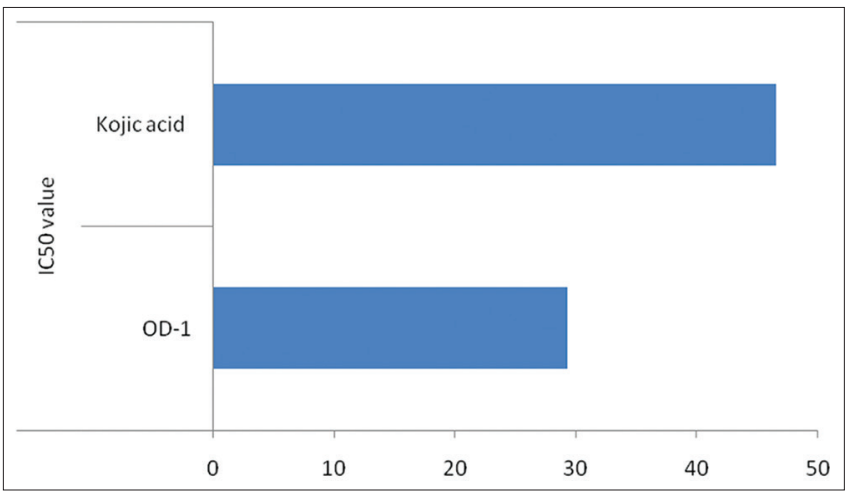

Fig. 7: $\mathrm{IC}_{50}$ values of compound $\mathrm{OD}-1$ and standard kojic acid

Table 3: IC $_{50}$ values of $0 D-1$ and standard kojic acid

\begin{tabular}{lll}
\hline Concentration & Log conc. & OD-1 \\
\hline 20 & 1.30103 & -174.19 \\
40 & 1.60206 & -169.6 \\
60 & 1.77815 & -150.5 \\
80 & 1.90309 & -146.23 \\
100 & 2 & -83.87 \\
$\mathrm{IC}_{50}$ value & OD-1 & 29.27 \\
& Kojic acid & 46.52 \\
\hline
\end{tabular}

The values are expressed in mean \pm S.D

\section{CONCLUSION}

DNA nanoparticles are a new revolution in technology of nanoscience. The DNA AgNPs of onion were synthesized by green method. Further, the green DNA AgNPs of onion were characterized by UV-visible, FTIR, SEM, XRD, and DLA methods. The characteristic UV-visible studies revealed the reduction of silver nitrate by the reducing agent DNA. The particle size was found to be $153 \pm 0.5 \mathrm{~nm}$ and they were found to be stable; the zeta potential value was found to be $<-30 \mathrm{meV}$. The XRD results revealed the face-centered cubic structure of the DNA nanoparticles and the SEM studies revealed that the particles shape was spherical with particle size of $150 \mathrm{~nm}$. Further, the DNA AgNPs were screened for in vitro antityrosinase activity using the standard kojic acid. The DNA AgNPs were found to have antityrosinase activity lower than the standard kojic acid. The research study can be further extended to report the in vivo anticancer potential.

\section{ACKNOWLEDGMENTS}

The authors express their gratitude to the CPS, IST, JNTUH, for providing necessary support during the course of the research work.

\section{AUTHORS' CONTRIBUTIONS}

Author 1 developed the theoretical format, worked with the analytic calculations, and performed the numerical simulations.

Both authors contributed to the final version of the manuscript. Author 2 supervised.

\section{CONFLICTS OF INTEREST}

The authors confirm that this article content has no conflicts of interest.

\section{REFERENCES}

1. Patil SD, Rhodes DG, Burgess DJ. DNA-based therapeutics and DNA delivery systems: A comprehensive review. AAPS J 2005;7:E61-77.

2. Lo PK, Metera KL, Sleiman HF. Self-assembly of three-dimensional DNA nanostructures and potential biological applications. Curr Opin Chem Biol 2010;14:597-607.

3. Wong KK, Liu X, et al. Silver nanoparticles the real silver bullet in clinical medicine. MedChemComm 2010;1:125-31.

4. Martinez-Gutierrez F, Olive PL, Banuelos A, Orrantia E, Nino N, Sanchez EM, et al. Synthesis, characterization, and evaluation of antimicrobial and cytotoxic effect of silver and titanium nanoparticles. Nanomedicine 2010;6:681-8.

5. Wink M. An Introduction to Molecular Biotechnology: Molecular Fundamentals, Methods and Application in Modern Biotechnology. Weinheim, Germany: Wiley-VCH; 2006.

6. Algar WR, Prasuhn DE, Stewart MH, Jennings TL, Blanco-Canosa JB, Dawson PE, et al. The controlled display of biomolecules on nanoparticles: A challenge suited to bioorthogonal chemistry. Bioconjug Chem 2011;22:825-58.

7. Kasyanenko N, Varshavskii M, Ikonnikov E, Tolstyko E, Belykh R, Sokolov P, et al. DNA modified with metal nanoparticles: Preparation and characterization of ordered Metal-DNA nanostructures in a solution and on a substrate. J Nanomater 2016;2016:3237250.

8. Marta CM, Villamiel M. An Overview of Bioactivity of Onion. New York: Nova Science Publishers, Inc.; 2012.

9. Harper A, Nickels K. DNA Extractions. Australia: Queensland University of Technology; 2008. p. 1-4.

10. Al-Sheddi ES, Farshori NN, Al-Oqail MM, Al-Massarani SM, Saquib Q, Wahab R, et al. Anticancer potential of green synthesized silver nanoparticles using extract of Nepeta deflersiana against human cervical cancer cells (HeLA). Bioinorg Chem Appl 2018;2018:9390784.

11. Ajitha B, Reddy YA, Shameer S, Rajesh KM, Suneetha Y, Reddy PS, et al. Lantana camara leaf extract mediated silver nanoparticles: Antibacterial, green catalyst. J Photochem Photobiol B 2015;149:84-92.

12. Devika R, Elumalai S, Manikandan E, Eswaramoorthy D. Biosynthesis of silver nanoparticles using the fungus Pleurotus ostreatus and their antibacterial activity. Open Access Sci Rep 2012;1:557.

13. Huang J, Li Q, Sun D, Lu Y, Su Y, Yang X, et al. Biosynthesis of silver 
and gold nanoparticles by novel sundried Cinnamomum camphora leaves. Nanotechnology 2007;18:105104-15.

14. Elassal M, El-Manofy N. Chitosan nanoparticles as drug delivery system for cephalexin and its antimicrobial activity against multiidrug resistent bacteria. Int J Pharm Pharm Sci 2019;11:14-27.

15. Gardouh A, Faheim SH, Solyman SM. Design, optimization and in vitro evaluation of antifungal activity of nanostructured lipid carriers of tolnaftate. Int J Pharm Pharm Sci 2019;11:109-15.

16. Mady M, El-Guendy N, Awad W, Elsayed AA. Interaction of DNA and polyethylamine: Fourier transform infrared (FTIR) differential scanning calorimetry (DSC) studies. Int J Phys Sci 2011;6:7238-334.

17. Volkov IL, Ramazanov RR, Ubyivovk EV, Rolich VI, Kononov AI, Kasyanenko NA, et al. Fluorescent silver nanoclusters in condensed DNA. Chem Phys Chem 2013;14:3543-50.

18. Zheng ZP, Cheng $\mathrm{KW}$, Zhu Q, Wang XC, Lin ZX, Wang M, et al. Tyrosinase inhibitory constituents from the roots of Morus nigra: A structure-activity relationship study. J Agric Food Chem 2010;58:5368-73 